\title{
Structure and shelf stability of milk protein gels created by pressure-assisted enzymatic gelation
}

Linran Wang $₫$ and Carmen I. Moraru* $\odot$

Department of Food Science, Cornell University, Ithaca, NY 14853

\section{ABSTRACT}

In this work, pressure-assisted enzymatic gelation was applied to milk proteins, with the goal of enhancing the structure and stability of pressure-created milk protein gels. High-pressure processing (HPP) at 600 $\mathrm{MPa}, 3 \mathrm{~min}$, and $5^{\circ} \mathrm{C}$ was applied to milk protein concentrate (MPC) samples of $12.5 \%$ protein concentration, both in the absence and in the presence of calf chymosin [up to 60 IMCU (international milk-clotting units) $/ \mathrm{kg}$ of milk] or camel chymosin (up to $45 \mathrm{IMCU} /$ $\mathrm{kg}$ of milk). Gel hardness, water-holding capacity, and degree of proteolysis were used to assess network strength and shelf stability. The processing trials and all measurements were conducted in triplicate. Statistical analyses of the data were performed by ANOVA, at a $95 \%$ confidence level. After HPP treatment, we observed significant structural changes for all samples. Pressurization of MPC, with or without chymosin addition, led to extensive protein aggregation and network formation. The strength of HPP-created milk protein gels without chymosin addition, as measured by the elastic modulus $\left(\mathrm{G}^{\prime}\right)$, had a value of $2,242 \mathrm{~Pa}$. The value of $G^{\prime}$ increased with increasing chymosin concentration, reaching as high as $4,800 \mathrm{~Pa}$ for samples with $45 \mathrm{IMCU} / \mathrm{kg}$ of camel chymosin. During 4 wk of refrigerated storage, the HPP and chymosin MPC gels maintained higher gel hardness and better structural stability compared with HPP only (no chymosin) MPC gels. The water-holding capacity of the gels without chymosin remained at $100 \%$ during $28 \mathrm{~d}$ of refrigerated storage. The HPP and chymosin MPC gels had a lower water-holding capacity (91-94\%) than the HPP-only counterparts, but their water-holding capacity did not decrease during storage. Overall, these findings demonstrate that controlled, fast structural modification of high-concentration protein systems can be obtained by HPP-assisted enzymatic treatment, and the created gels have a strong, stable network. This study provides insights into the possibility of using HPP for the de-

Received August 16, 2020.

Accepted November 1, 2020.

*Corresponding author: cim24@cornell.edu velopment of milk-protein-based products with novel structures and textures and long refrigerated shelf life, along with the built-in safety imparted by the HPP treatment.

Key words: high-pressure processing, chymosin, milk protein concentrate, gelation, shelf stability

\section{INTRODUCTION}

The food market maintains a strong interest in highprotein products, and the development of new proteinrich products is a significant focus of activity in many food companies. Among the sources of food proteins, milk proteins are very popular because of their clean taste, excellent nutritional value, and good digestibility. Traditionally, milk proteins represent the structural basis for dairy foods such as cheese and yogurt. The gelation processes involved in manufacturing these products, which includes fermentation and coagulation, require extended reaction time, typically hours, and are not easy to control. Recently, high-pressure processing (HPP) has attracted the interest of the food industry as an alternative nonthermal processing method that can induce in-package gelation of milk proteins (Devi et al., 2013; Cadesky et al., 2017). Cadesky et al. (2017) reported that HPP of milk protein concentrate (MPC) at $450 \mathrm{MPa}$ for $15 \mathrm{~min}$, at $\sim 20^{\circ} \mathrm{C}$, created self-supporting gels, at a protein concentration of at least $10 \%$ (wt/ wt). However, the structure of the resulting physical gels is relatively weak, as they are held together by noncovalent bonds. Therefore, solutions to enhance the strength and stability of such gels could be very beneficial for their utilization in practical applications.

Chymosin is the milk-coagulating enzyme typically used in the production of cheese, which acts by cleaving the $\kappa$-casein molecules positioned at the surface of casein micelles. High-pressure processing has been shown to alter the natural conformation of chymosin and affect its activity in a buffer system, but not in a negative way. It was previously reported that the activity of chymosin increases with pressures up to 300 $\mathrm{MPa}$, with an optimum at $212 \mathrm{MPa}$ (Leite Júnior et al., 2016). Moreover, Ribeiro et al. (2017) also showed that pressures in the range from 200 to $400 \mathrm{MPa}$, at room 
temperature, can enhance the activity of chymosin. These findings suggest that chymosin may be able to participate in the HPP-mediated coagulation of milk proteins, leading to increased strength of the pressureinduced milk protein gels.

Most studies published so far have focused on the activity of chymosin treated by HPP in substrate-free buffer systems, and the behavior of chymosin under pressure in a high-concentration protein system is likely to be different. It can be expected that combining HPP and chymosin treatment will induce a higher enzymatic reaction rate, due to the increased enzymatic activity and greater substrate exposure (Bamdad et al., 2017). To the best of our knowledge, no data has been published yet on the effect of a combined HPP-chymosin treatment in high-concentration milk protein systems. Therefore, the objective of this work was to investigate the properties and shelf stability of milk gels created by a combined HPP-chymosin treatment. This study will provide the dairy industry with data and information necessary to design novel dairy products with interesting new structures, as well as built-in safety and extended shelf life, as the HPP treatment is known to inactivate vegetative microflora.

\section{MATERIALS AND METHODS}

\section{Creation of Milk Protein Gels}

Sample Preparation. Milk protein concentrate (MPC) 852A was provided by Ingredia Inc. (Wapakoneta, $\mathrm{OH}$ ). The composition of the MPC, as determined at Dairy One Forage Laboratory (Ithaca, NY), was as follows: protein: $81.49 \mathrm{~g} / 100 \mathrm{~g}$, moisture: $5.63 \mathrm{~g} / 100$ $\mathrm{g}$, ash: $6.66 \mathrm{~g} / 100 \mathrm{~g}$, lactose: $5.06 \mathrm{~g} / 100 \mathrm{~g}$, and fat: $1.16 \mathrm{~g} / 100 \mathrm{~g}$ (wt/wt). The study was conducted on MPC samples of $12.5 \mathrm{~g}$ of protein/100 g, a concentration chosen because it is above the critical gelation concentration for pressure-induced milk protein gelation (Cadesky et al., 2017) and close to the solubility limit of the MPC powder. The protein powder was weighed and slowly dispersed in Milli-Q (Millipore Sigma, Burlington, MA) purified water to obtain milk protein suspensions with target protein concentration of $12.5 \%$. To ensure suitable dispersion and hydration of the protein, the suspensions were first mixed using an Omni-Mixer model 17105 (Omni International, Kennesaw, GA), at a speed setting of $10(18,000 \mathrm{rpm})$ for $7.5 \mathrm{~min}$. The samples were then kept under continuous stirring at $400 \mathrm{rpm}$ at $5^{\circ} \mathrm{C}$ for an additional $12 \mathrm{~h}$ to allow foam breaking and complete hydration of the milk proteins.

Chymosin Addition. Calf chymosin with an activity of 626 international milk-clotting units (IMCU)/g (Chy-Max Extra, Chr. Hansen Inc., Milwaukee, WI) or camel chymosin with an activity of $961 \mathrm{IMCU} / \mathrm{g}$ (ChyMax M, Chr. Hansen Inc.), diluted 1:10 in deionized water, was added to the MPC suspensions, at target enzyme concentrations of $30,45 \mathrm{~m}$ and $60 \mathrm{IMCU} / \mathrm{kg}$ of milk at $5^{\circ} \mathrm{C}$. The enzyme concentrations were chosen to represent the most commonly used chymosin dosages for cheese making: 30 to $60 \mathrm{IMCU} / \mathrm{kg}$ of milk for calf chymosin, and 30 to $45 \mathrm{IMCU} / \mathrm{kg}$ of milk for camel chymosin. Immediately after adding chymosin, the samples were thoroughly mixed and sealed in flexible packaging, and then kept under refrigeration for a maximum of 10 min before pressurization.

High-Pressure Processing. The packaged MPC suspensions were pressurized using a 55-L HPP unit (Hiperbaric USA, Miami, FL) at the Cornell High Pressure Processing Validation Center (Geneva, NY). Water was used as the pressure-transmitting medium. The temperature of the pressurization water was preequilibrated to $5^{\circ} \mathrm{C}$ for at least $1 \mathrm{~h}$ before the treatment. Samples were then subjected to pressurization at $600 \mathrm{MPa}$ for $3 \mathrm{~min}$, at $5^{\circ} \mathrm{C}$. These conditions were selected because they are typical conditions used for HPP inactivation of foodborne pathogens and because they were demonstrated to induce structure formation in milk proteins, based on our earlier work (Wang and Moraru, 2021). The water temperature during the processes was between $5^{\circ} \mathrm{C}$ and $8^{\circ} \mathrm{C}$. The come-up time to reach $600 \mathrm{MPa}$ was $132 \mathrm{~s}$, and depressurization was achieved in $2 \mathrm{~s}$.

As controls, MPC samples that were not subjected to HPP treatment, both without and with chymosin addition, were used. These samples were prepared and handled in the same way as the HPP-treated sample, minus the HPP treatment. The controls are called "untreated (no HPP)" throughout the article.

\section{Structural Analysis of Milk Protein Gels}

Small Deformation Oscillatory Rheological Analysis. A strain-controlled rheometer equipped with a Peltier temperature control system (TA Instruments, New Castle, DE) was used to run oscillatory dynamic measurements. Before the rheological measurements, gel samples were carefully cut into slices of $25-\mathrm{mm}$ diameter and 2-mm height. The gel slices were placed between the lower plate and a 25-mm-diameter Teflon parallel plate, with a 2-mm inter-plate gap. For samples that could flow, 2-mL aliquots were loaded onto the lower plate and a 50-mm-diameter Teflon parallel plate with a 1-mm inter-plate gap was used. All measurements were performed at $4^{\circ} \mathrm{C}$. An isothermal chamber enclosed the parallel plates to minimize sample dehydration during measurements. The samples were subjected to a 1-min relaxation step before measurement. 
The linear viscoelastic region (LVR) was first identified for each sample by running dynamic strain sweeps over the strain interval 0.5 to $5 \%$, at a frequency of $1 \mathrm{rad} / \mathrm{s}$. Afterward, frequency sweep tests were carried out in the frequency range 0.1 to $100 \%$, using a strain value in the LVR, and the storage (elastic) modulus $\left(\mathbf{G}^{\prime}\right)$, loss (viscous) modulus $\left(\mathbf{G}^{\prime \prime}\right)$, and loss tangent ( $\left.\tan \boldsymbol{\delta}\right)$ were recorded. The frequency sweep tests run over at least 3 decades of frequency give information about the strength and lifetime of major interactions, and therefore can be used to predict the type of gel (Tunick, 2011). Here, the $\mathrm{G}^{\prime}$ versus frequency dependence $(m)$ was quantified using the following equation:

$$
\log \left(\mathrm{G}^{\prime}\right)=m \log (\omega)+K,
$$

where $m$ and $K$ are constants, $\omega$ is the oscillation frequency, and $G^{\prime}$ is the storage modulus.

All rheological measurements for each processing replicate were performed in duplicate.

Microstructural Analysis by Scanning Electron Microscopy. Samples for scanning electron microscopy were prepared in a way designed to maintain their structural integrity, using the procedure described by Feng et al. (2014), with modifications. Samples were sliced into thin slices using a disposable scalpel. For the primary fixation, samples were treated with $2.5 \%$ (wt/ vol) glutaraldehyde solution in $0.05 \mathrm{M}$ sodium cacodylate buffer for $2 \mathrm{~h}$ and washed with the cacodylate buffer 3 times for 5 min each time. For the secondary fixation, samples were treated with $1 \%$ (wt/vol) osmium tetroxide in cacodylate buffer for $1 \mathrm{~h}$ and rinsed again with cacodylate buffer 3 times, for 5 min each time. Samples were then dehydrated with graded ethanol solutions of $25,50,70$, and $95 \%$ (vol/vol) and 3 times with a graded ethanol solution of $100 \%$ for 10 min each, then critical-point dried using carbon dioxide. Dried samples were mounted on scanning electron microscopy stubs with carbon tape, and thinly coated with a gold/palladium alloy. A Zeiss LEO 1550 field emission scanning electron microscope (Carl Zeiss Microscopy LLC, Jena, Germany) was used, at a voltage of $3 \mathrm{kV}$, and images were acquired using the instrument accompanying software SmartSEM (Carl Zeiss Microscopy LLC).

\section{Shelf Stability of Milk Protein Gels}

After the HPP treatment, samples were stored at $4 \pm 0.2^{\circ} \mathrm{C}$ for $28 \mathrm{~d}$, and their water-holding capacity, texture, and degree of proteolysis were monitored.

Gel Water-Holding Capacity. Water-holding capacity (WHC) of the MPC gels was determined according to AACC International method 56-30112
(AACC, 2009), with modifications. Five-gram samples were centrifuged at $2,000 \times g$ for $10 \mathrm{~min}$ at $5^{\circ} \mathrm{C}$. After centrifugation and removing the supernatant, the pellet was weighed, and the WHC was calculated as $100 \%$ $\times$ (pellet weight/initial sample weight). The measurements were carried out on d $0,7,14,21$, and 28 in triplicate.

Textural Analysis. Gel texture was evaluated using a TA-XTPlus texture analyzer (Stable Micro Systems, Godalming, UK) equipped with an acrylic cylinder probe (35 $\mathrm{mm}$ in diameter). Samples were cut into cylindrical shapes of $25 \mathrm{~mm}$ (diameter) and $10 \mathrm{~mm}$ (height). Single-compression measurements were performed on the MPC gels at $40 \%$ strain and a speed of $1 \mathrm{~mm} / \mathrm{s}$. Gel hardness (expressed in grams) was defined as the peak force on the force-deformation curve. Textural analyses were carried out on d $0,7,14,21$, and 28 in triplicate.

Peptide Concentration Determination. To gain insight into sample proteolysis during storage, the concentration of peptides that may have resulted from the residual proteolytic activity of chymosin after the HPP treatment was evaluated. For this, samples were mixed with $1 \mathrm{~N}$ sodium hydroxide, followed by ultrafiltration at $7,500 \times g$ in Amicon Ultra-4 centrifugal filter devices (MilliporeSigma) with a molecular weight cutoff of $10 \mathrm{kDa}$. The concentration of peptides $<10 \mathrm{kDa}$ was measured using the bicinchoninic acid method (Pierce BCA Assay, Thermo Fisher Scientific, Waltham, MA). The absorbance of peptides mixtures was determined at $562 \mathrm{~nm}$ using a spectrophotometer (SpectraMax iD3; Molecular Devices Limited, San Jose, CA). The peptide concentration $(\mathrm{mg} / \mathrm{g})$ was calculated from a BSA standard curve.

\section{Statistical Analysis}

The processing trials were conducted in triplicate, using a fresh sample preparation each time; all analytical measurements were also conducted in triplicate. Data were analyzed using JMP 14 Pro software (SAS Institute Inc., Cary, NC). Statistical differences among means were determined using one-way ANOVA with a significance level $\alpha=0.05$.

\section{RESULTS AND DISCUSSION}

\section{Effect of Chymosin Addition and HPP on Gel Strength}

After the 3-min HPP treatment, gels were formed in all HPP-treated MPC samples. Pressurization of MPC with chymosin addition led to more extensive protein aggregation and network formation than in the 
(a)

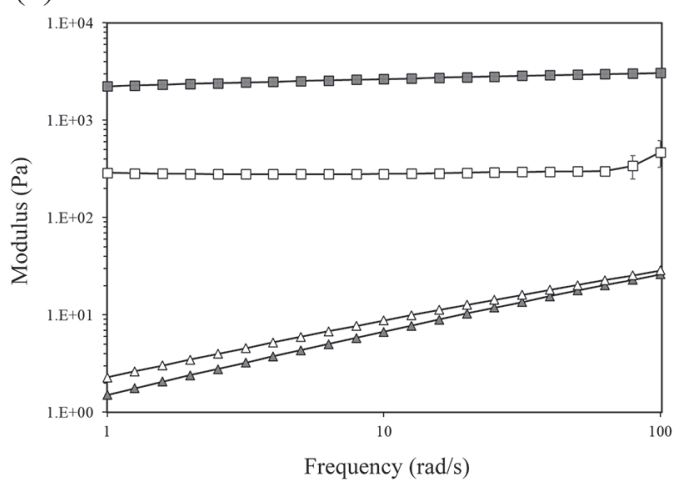

(c)

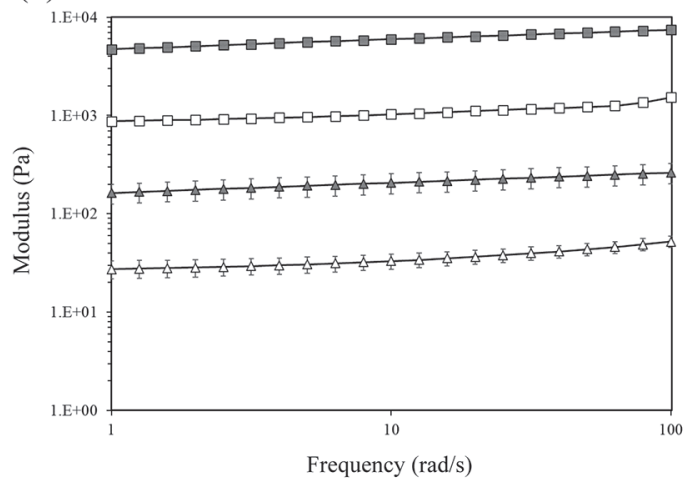

(e)

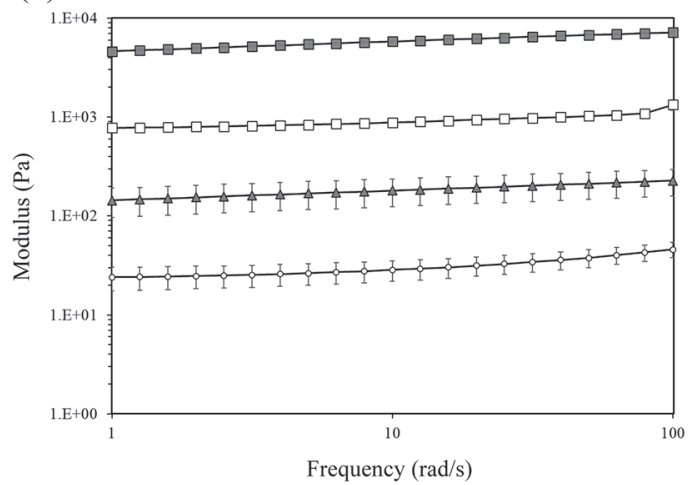

(b)

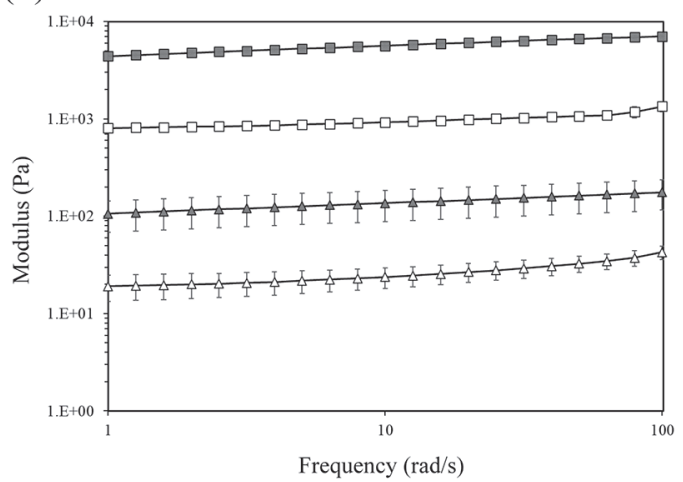

(d)

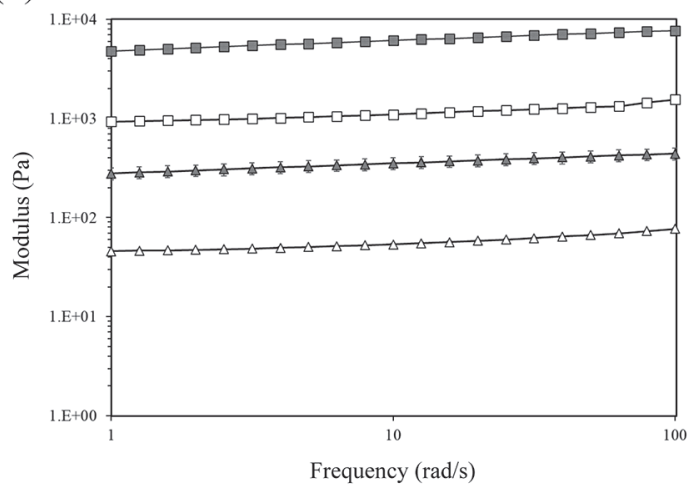

(f)

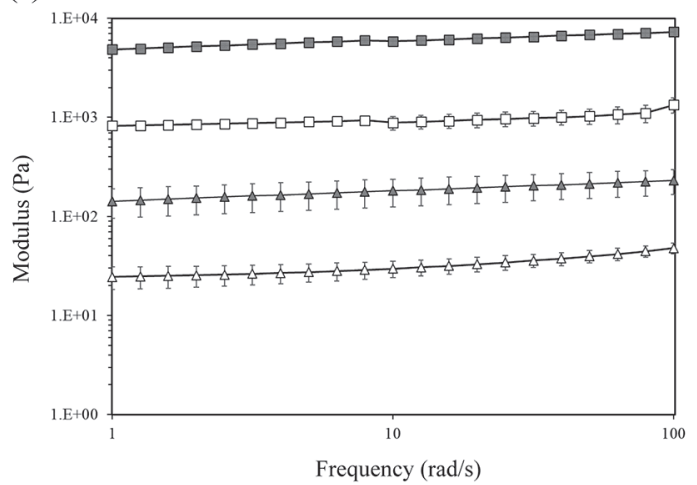

Figure 1. Frequency sweeps (storage modulus, G', and loss modulus, G") for untreated (no high-pressure processing, HPP) and HPP-treated milk protein concentrate with different chymosin types and concentrations: (a) no chymosin, (b) 30 international milk-clotting units (IMCU)/kg of calf chymosin, (c) $45 \mathrm{IMCU} / \mathrm{kg}$ of calf chymosin, (d) $60 \mathrm{IMCU} / \mathrm{kg}$ of calf chymosin, (e) $30 \mathrm{IMCU} / \mathrm{kg}$ of camel chymosin, and (f) $45 \mathrm{IMCU} / \mathrm{kg}$ of camel chymosin, where $\left(\mathrm{G}^{\prime}\right)$ and $\square\left(\mathrm{G}^{\prime \prime}\right)=$ HPP treated and $\boldsymbol{\Delta}\left(\mathrm{G}^{\prime}\right)$ and $\Delta\left(\mathrm{G}^{\prime \prime}\right)=$ untreated (no HPP). Error bars indicate 1 SD $(\mathrm{n}=6)$.

samples without added chymosin. In this study, both calf chymosin and camel chymosin were used, as they have slightly different coagulation properties.

To quantify the effect of chymosin addition on gel strength, frequency sweep tests were performed for both the untreated (no HPP) and HPP-treated MPC samples with different chymosin concentrations (Figure 1). All MPC samples formed gels after being HPP treated, and the gel strength values varied as a function of chymosin addition.
Although calf chymosin and camel chymosin were added at various concentrations, no significant differences were found in the gels' viscoelastic character. As indicated by Figure 1, the untreated MPC was characterized by a dominant $\mathrm{G}^{\prime \prime}$ over the entire frequency range (1-100 rad/s), indicating a liquid-like behavior. All MPC samples formed gels after being treated by HPP, chymosin or the combination of HPP and chymosin. For these samples, $G^{\prime}$ was much higher than $\mathrm{G}^{\prime \prime}$ over the entire frequency range, indicating a solid- 


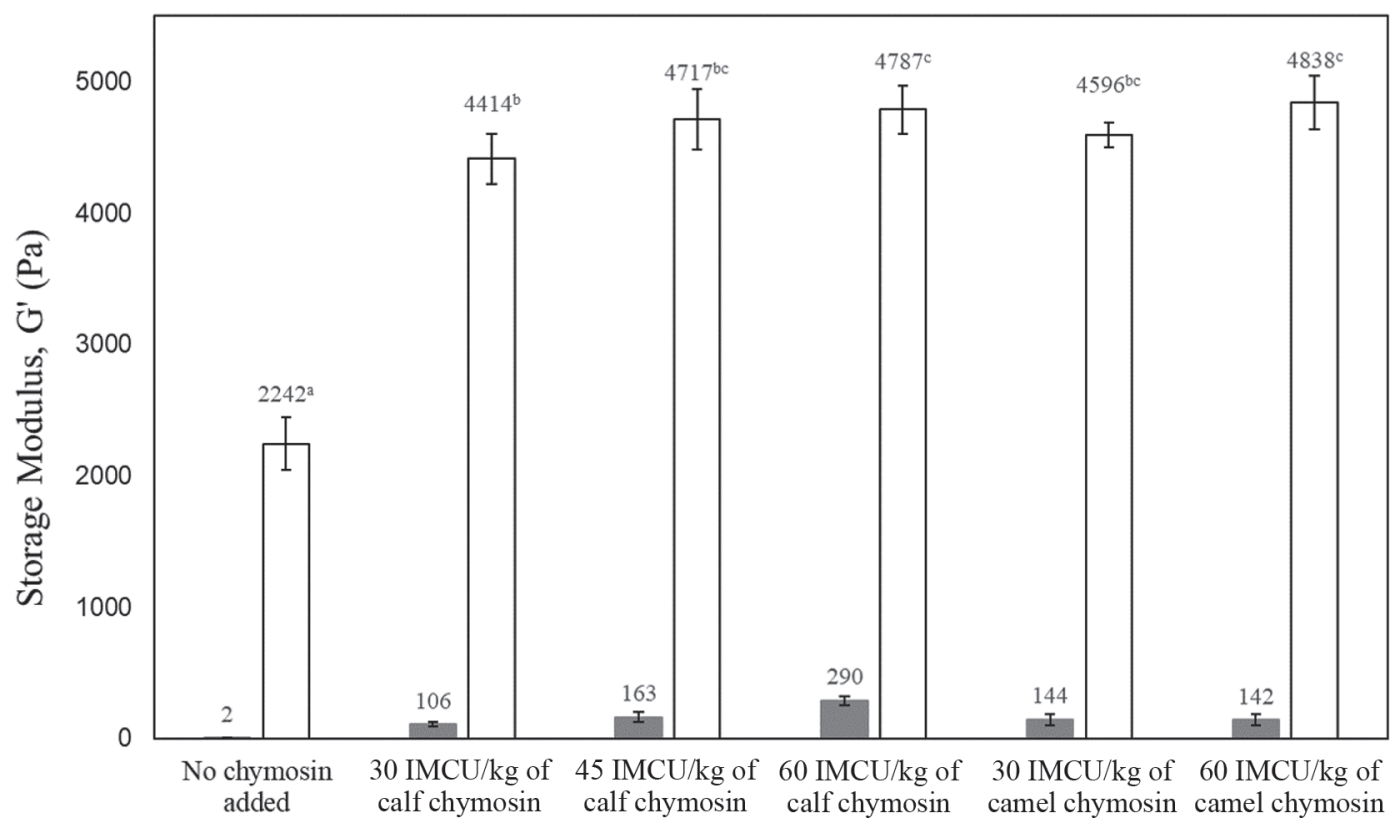

Figure 2. Storage modulus $\left(\mathrm{G}^{\prime}\right)$ for untreated (no high-pressure processing; gray bars) and high-pressure processing-treated (white bars) milk protein concentrate with different chymosin types (calf and camel) and concentrations (30, 45, and 60 international milk clotting units, IMCU). Error bars represent $1 \mathrm{SE}(\mathrm{n}=3)$. Data points with different letters $(\mathrm{a}-\mathrm{c})$ are significantly different from each other $(P<0.05)$.

like behavior. To perform direct comparisons between samples' viscoelastic behavior, storage modulus $\left(\mathrm{G}^{\prime}\right)$ and loss tangent $(\tan \delta)$ at $1 \mathrm{rad} / \mathrm{s}$ for untreated and pressure-treated samples were extracted from their frequency sweeps and plotted in Figure 2 and Figure 3. The $\mathrm{G}_{1 \mathrm{rad} / \mathrm{s}}$ value indicates a sample's gel strength, and $\tan \delta_{1 \mathrm{rad} / \mathrm{s}}$ is the ratio between the samples' viscous modulus $\left(\mathrm{G}^{\prime \prime}\right)$ and elastic modulus $\left(\mathrm{G}^{\prime}\right)$, and a quantitative indicator of a liquid-like or solid-like behavior.

In general, gels made by the combined HPP-chymosin treatment exhibited higher gel strength than the gels without chymosin (Figure 2). There were no significant differences in the $G^{\prime}$ value of the gels with calf chymosin versus camel chymosin, indicating that the source of chymosin (calf or camel) had no effect on gel strength. Adding chymosin doubled the gel strength of the HPP-treated samples, although $\mathrm{G}^{\prime}$ did not increase proportionally to the chymosin concentration. The gel strength achieved by the combined HPP-chymosin treatment $\left(\mathrm{G}^{\prime}{ }_{1 \mathrm{rad} / \mathrm{s}} \sim 4,800 \mathrm{~Pa}\right)$ was much higher than the sum of the gel strength obtained with individual treatments $(\sim 2,400 \mathrm{~Pa})$, indicating that chymosin strongly reinforced the pressure-created milk gels. This effect most likely reflects the enhanced enzymatic activity by pressurization, which aided the chymosin-catalyzed cross-linking of caseins, which happened in addition to the pressure-induced noncovalent interactions responsible for pressure-induced gelation of milk proteins.

All pressure-treated samples had tan $\delta_{1 \mathrm{rad} / \mathrm{s}}<0.2$ (Figure 3), indicating a strong solid-like behavior. In- terestingly, the tan $\delta_{1 \mathrm{rad} / \mathrm{s}}$ values of HPP chymosin gels were slightly higher than for the MPC gels without chymosin, indicating that the intermolecular bonds in HPP chymosin gels could be broken and reformed more easily than in the HPP gels without chymosin (Renkema et al., 2002).

For all treatments, frequency dependence $(m)<0.12$ (Table 1), indicating that HPP, chymosin, and HPPchymosin-combined treatments all resulted in strong cross-linked gels (Tunick, 2011). Irrespective of HPP treatment and the chymosin type, there were no significant differences in $m$ among samples that contained chymosin, indicating that the nature of the bonds did not change upon pressurization. The fact that $G^{\prime}$ increased by 30 - to 40 -fold in samples treated with chymosin and HPP compared with the unpressurized counterparts indicates that the increase in gel firmness may have been caused by an increase in the number of bonds after HPP treatment.

Casein micelles dissociate into sub-micelles upon pressurization, due to the solubilization of calcium and diminished hydrophobic interactions (Cadesky et al., 2017). These sub-micelles may provide easier access to an increased number of active $\kappa-\mathrm{CN}$ sites for the chymosin, as well as more efficient enzymatic reaction caused by a higher rate of enzyme diffusion in the compressed solution (Bamdad et al., 2017). Additionally, individual caseins previously buried in the micelle core (e.g., $\alpha_{\mathrm{S}_{2}} \mathrm{CN}$ ) become exposed and interact with each other through calcium bonding and hydrophobic and 


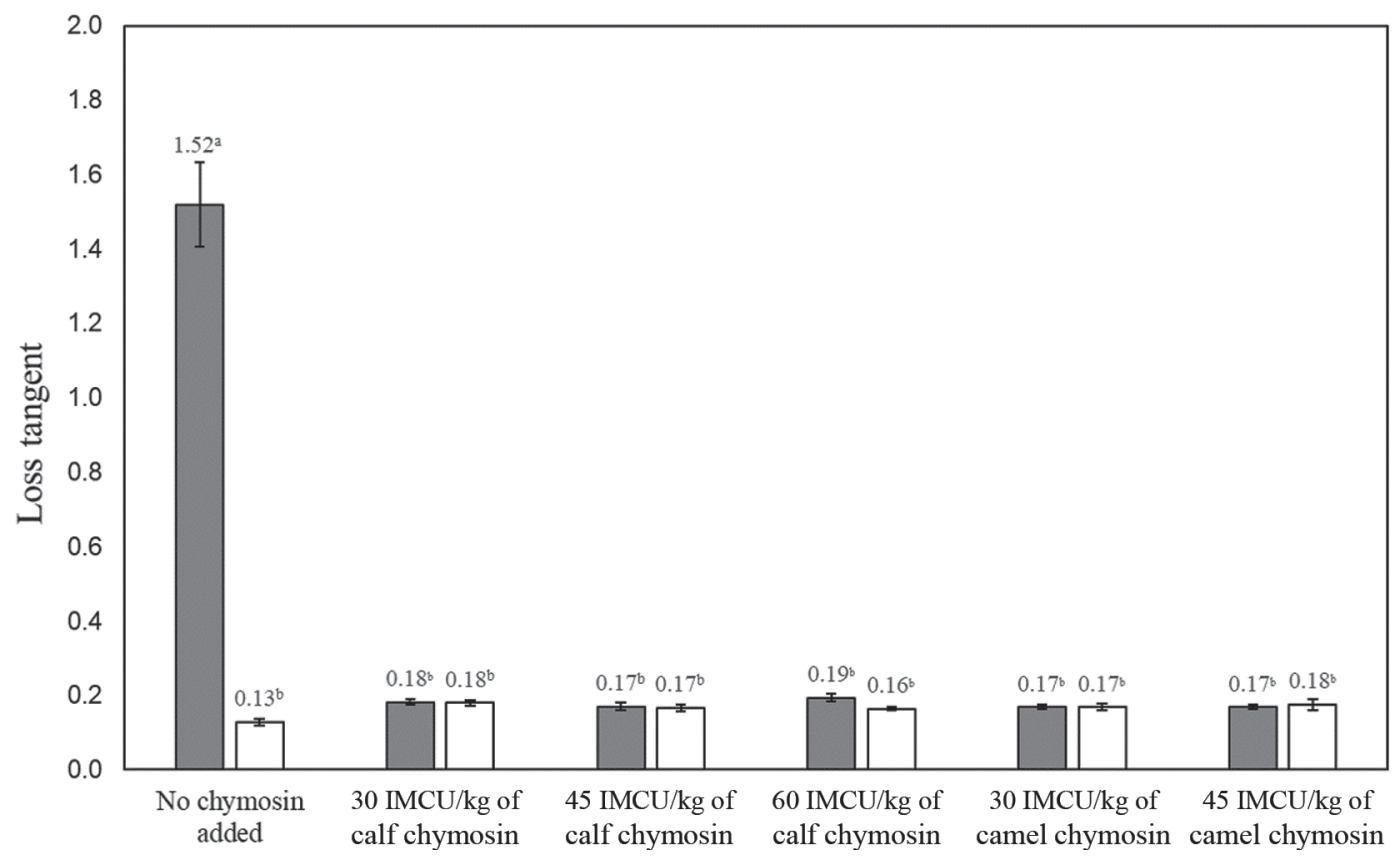

Figure 3. Loss tangent $(\tan \delta$ ) for untreated (no high-pressure processing; $\mathbf{\square})$ and high-pressure processing-treated $(\square)$ milk protein concentrate samples with different chymosin types (calf and camel) and concentrations (30, 45, and 60 international milk clotting units, IMCU). Error bars represent $1 \mathrm{SE}(\mathrm{n}=3)$. Data points with different letters $(\mathrm{a}, \mathrm{b})$ are significantly different from each other $(P<0.05)$.

electrostatic interactions. All of these contribute to a more compact gel structure, characterized by higher gel strength of the HPP and chymosin gels compared with HPP-only gels. For the HPP-treated samples, the addition of chymosin led to slightly increased $m$ values, from $0.08 \pm 0.002$ to $0.11 \pm 0.003$. The increase in the viscous behavior may be due to the lowering of the repulsive barrier among casein particles due to chymosin

Table 1. Frequency dependence parameter $(m)$ for milk protein concentrate samples (12.5\% protein) that were untreated (no highpressure processing, HPP) or treated with HPP without chymosin or with different chymosin types (calf or camel) and concentrations ${ }^{1}$

\begin{tabular}{lllc}
\hline Treatment & $\begin{array}{l}\text { IMCU } / \mathrm{kg} \\
\text { ofchymosin }\end{array}$ & $\begin{array}{l}\text { Chymosin } \\
\text { type }\end{array}$ & $m$ \\
\hline HPP only & - & - & $0.08 \pm 0.002^{\mathrm{a}}$ \\
HPP & 30 & Calf & $0.11 \pm 0.003^{\mathrm{b}}$ \\
& 45 & Calf & $0.11 \pm 0.009^{\mathrm{b}}$ \\
& 60 & Calf & $0.11 \pm 0.007^{\mathrm{b}}$ \\
& 30 & Camel & $0.10 \pm 0.001^{\mathrm{b}}$ \\
Untreated & 45 & Camel & $0.09 \pm 0.020^{\mathrm{ab}}$ \\
& 40 & Calf & $0.11 \pm 0.006^{\mathrm{b}}$ \\
& 60 & Calf & $0.11 \pm 0.005^{\mathrm{b}}$ \\
& 30 & Calf & $0.11 \pm 0.002^{\mathrm{b}}$ \\
& 45 & Camel & $0.11 \pm 0.004^{\mathrm{b}}$ \\
& & Camel & $0.11 \pm 0.011^{\mathrm{b}}$ \\
\hline
\end{tabular}

$\overline{\mathrm{a}, \mathrm{b}}$ Different letters indicate significant differences $(P<0.05)$ between $m$ values.

${ }^{1}$ Values represent mean \pm standard error; $\mathrm{n}=6$ for all measurements. ${ }^{2} \mathrm{IMCU}=$ international milk-clotting units. hydrolysis, resulting in the formation of casein strands that easily break at high frequency (Lucey, 2011; Grillet et al., 2012).

Finally, because the treatment effects observed here were not dependent on chymosin concentration, the subsequent experiments focusing on microstructure and structural stability were only performed at a chymosin activity of $45 \mathrm{IMCU} / \mathrm{kg}$.

\section{Microstructure of the Pressure and Chymosin Gels}

The differences in milk protein gels' structure revealed by rheological analyses were supported by observations of their 3-dimensional protein network, performed by scanning electron microscopy. Figure 4 shows representative micrographs for MPC gels created by HPP and HPP-chymosin treatment.

All MPC gels exhibited fine-stranded gel structures, with subunits represented by spherical micro-aggregates. The HPP-treated, no chymosin gels had a uniform, fine-meshed network of small casein aggregates. In contrast, the gels that included chymosin had more aggregated protein networks, with larger interstitial spaces between the structural elements and larger clusters linked together. Although we observed slight differences in the network homogeneity and compactness, gels with calf or camel chymosin showed a similar structure. 
HPP-treated, no chymosin added
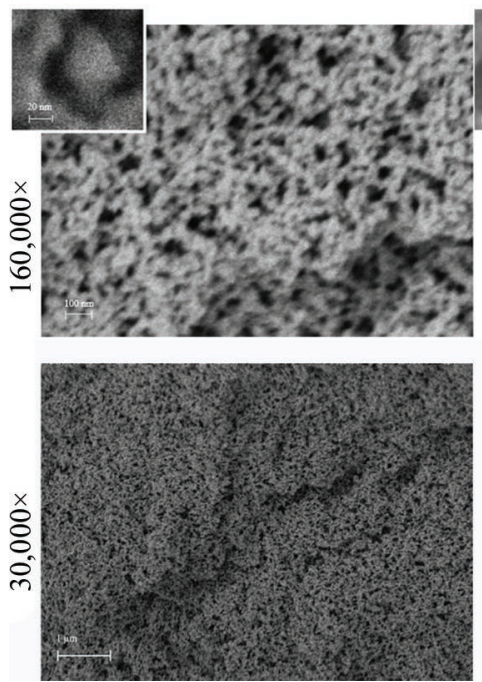

HPP-treated, calf chymosin added
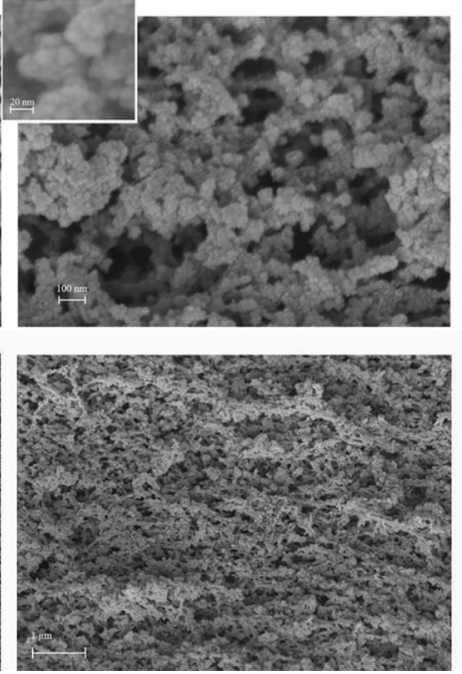

HPP-treated, camel chymosin added
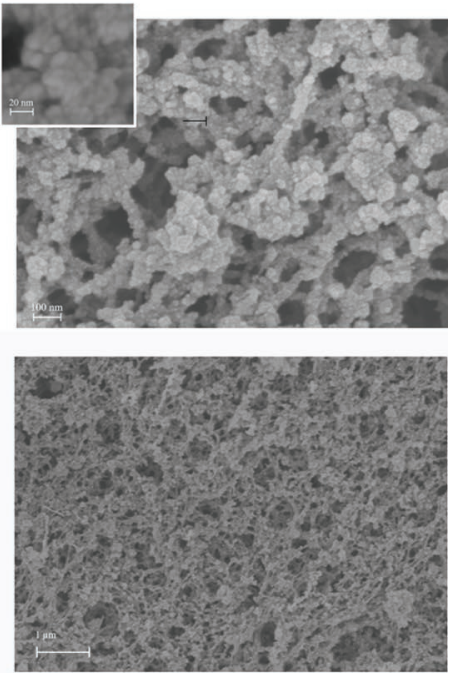

Figure 4. Scanning electron micrographs for high-pressure processing (HPP)-treated no chymosin milk protein concentrate (MPC) gel, HPPtreated calf chymosin MPC gel, and HPP-treated camel chymosin MPC gel at magnifications of 30,000× $(\mathrm{scale}$ bar $=1 \mu \mathrm{m})$ and $160,000 \times(\mathrm{scale}$ bar $=100 \mathrm{~nm}$ ). The inserts in the upper panels represent magnified views of some of the structures observed in the main images.

\section{Gel Stability During Refrigerated Shelf Life}

Textural Stability During Refrigerated Shelf Life. The gels produced by HPP are physical gels that are held together mainly by noncovalent bonds such as hydrogen bonds and hydrophobic interactions, and therefore have limited structural stability and lifetime (Fertsch et al., 2003; Ma et al., 2012). This can have negative implications for the stability of food products based on such structures.

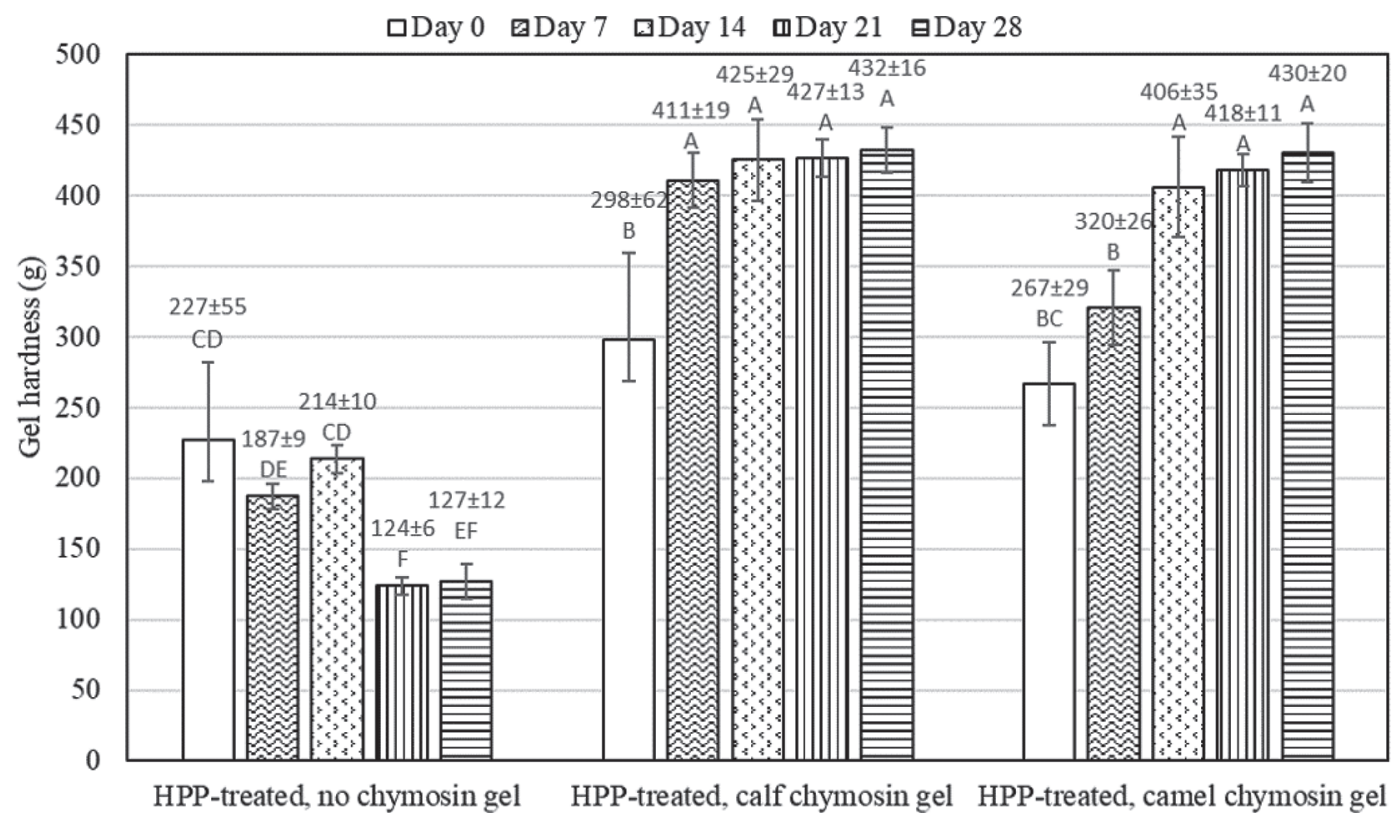

Figure 5. Changes in gel hardness $(\mathrm{g})$ of samples with no chymosin, calf chymosin, or camel chymosin during storage at $4^{\circ} \mathrm{C}$. The value of gel hardness was affected by both chymosin addition $(P<0.05)$ and the storage period $(P<0.05)$. White bar $=\mathrm{d} 0$, wavy bar $=\mathrm{d} 7$, bar with pattern $=\mathrm{d} 14$, bar with vertical lines $=\mathrm{d} 21$, and bar with horizontal lines $=\mathrm{d} 28$. For gels without chymosin, hardness decreased from $227 \pm$ $55 \mathrm{~g}(\mathrm{CD})$ immediately after treatment to $127 \pm 12 \mathrm{~g}(\mathrm{EF})(\sim 45 \%$ of the initial value) at wk 4 . Error bars represent $1 \mathrm{SD}(\mathrm{n}=6)$. Data points with different letters $(\mathrm{A}-\mathrm{F})$ are significantly different from each other $(P<0.05)$. Chymosin concentration used: 45 international milk clotting units $/ \mathrm{kg}$. 
To monitor changes in the gel structure, gel hardness was determined immediately after treatment and during refrigerated storage. Figure 5 shows the gel hardness of samples with no chymosin or the 2 types of chymosin (calf or camel) during storage at $4^{\circ} \mathrm{C}$. The value of gel hardness was affected by both chymosin addition $(P<$ $0.05)$ and the storage period $(P<0.05)$. Hardness was lower for gels without chymosin than for chymosin gels, and the difference in hardness was much greater at the end of the $28 \mathrm{~d}$ of refrigerated storage. Gel hardness decreased from $227 \pm 55 \mathrm{~g}$ immediately after treatment to $127 \pm 12 \mathrm{~g}(\sim 45 \%$ of the initial value) at $\mathrm{d} 28$. This reduction of hardness can be attributed to the weakening of non-covalent bonds during refrigeration, which leads to a looser protein network.

High-pressure processing-created MPC gels with calf or camel chymosin showed a markedly higher hardness than the no-chymosin gels, and these differences became more pronounced at the end of the $28 \mathrm{~d}$ of refrigerated storage. There were no significant differences in the hardness of the gels with calf chymosin versus camel chymosin, except that the hardness of the calf chymosin gel was higher than the hardness of camel chymosin gel on d 7. Furthermore, on d 14 the hardness of calf chymosin gels and camel chymosin gels was higher by $\sim 40 \%$ and $\sim 50 \%$ than no-chymosin gels, respectively. These effects are likely a consequence of the chymosin-catalyzed cross-linking of caseins, which increases the gel hardness. It should also be noted that we observed a low level of syneresis in both type of chymosin gels throughout shelf life storage. The reasons for this effect will be discussed in the next section, but this might explain the observed increase in gel strength for the chymosin gels during refrigerated storage.

WHC During Refrigerated Shelf Life. The ability of the milk protein gels to retain water was not affected by storage period, as shown in Figure $6(P$ $<0.05)$. Water-holding capacity of HPP-created milk

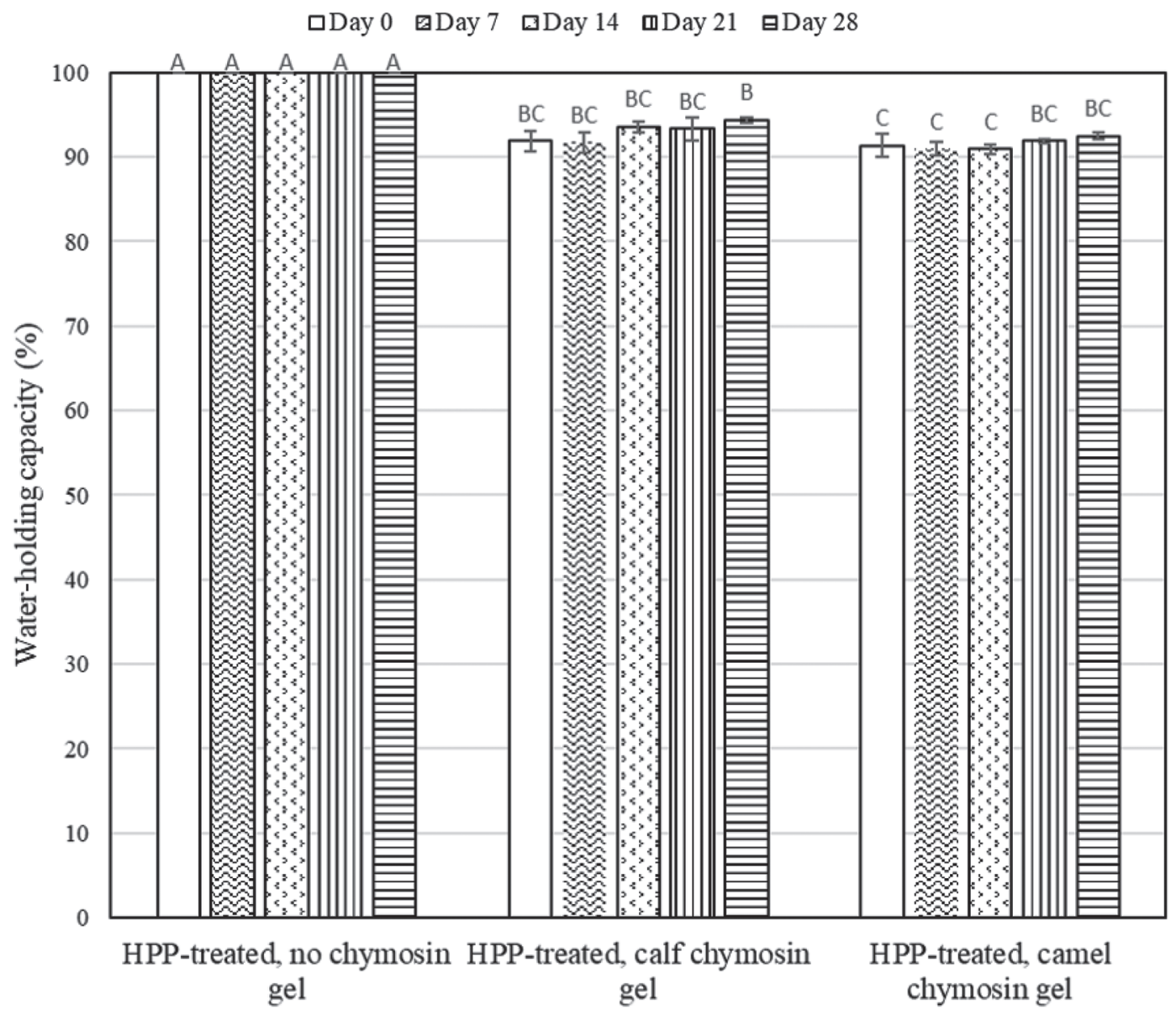

Figure 6. Changes in water-holding capacity (\%) of milk protein concentrate gels during $28 \mathrm{~d}$ of refrigerated storage time at $4^{\circ} \mathrm{C}$. White bar $=\mathrm{d} 0$, wavy bar $=\mathrm{d} 7$, bar with pattern $=\mathrm{d} 14$, bar with vertical lines $=\mathrm{d} 21$, and bar with horizontal lines $=\mathrm{d} 28$. Error bars represent $1 \mathrm{SD}(\mathrm{n}=6)$. Data points with different letters $(\mathrm{A}-\mathrm{C})$ are significantly different from each other $(P<0.05)$. Chymosin concentration used: 45 international milk-clotting units $/ \mathrm{kg}$. 
protein gels remained at $100 \%$ during the $28 \mathrm{~d}$ of refrigeration, which is indicative of excellent structural stability and water retention.

Interestingly, chymosin gels presented a lower WHC than the gels with no chymosin, although their WHC did not decrease during storage. This difference in WHC can be explained by the morphological differences between gels, as observed in the scanning electron micrographs in Figure 4. The no-chymosin gels had a homogeneous, fine-meshed network, which was able to retain water well during refrigerated storage. This agrees with Domagała et al. (2016), who observed that finely structured and highly interconnected casein networks have high water retention. By contrast, gels created by the combined HPP-chymosin treatment had a compact network, with larger pores and higher permeability, which allowed the flow of liquid and facilitated drainage and separation of water and serum.

Proteolysis During Shelf Life. It has been reported that treatment of many cheese varieties at a pressure $\geq 600 \mathrm{MPa}$ does not inactivate chymosin completely (Huppertz et al., 2004; Scollard et al., 2000). Though loss of more than $90 \%$ chymosin activity was reported after treatment at $600 \mathrm{MPa}$ (Huppertz et al., 2004), any residual chymosin in the MPC gels could lead to primary proteolysis after pressurization, causing undesirable changes in product quality such as the formation of bitter flavors. Hence, it was important to assess the level of proteolysis in MPC gels that contained chymosin.
We investigated proteolysis of the HPP-created milk protein gels by determining the percentage of peptides with a molecular mass $<10 \mathrm{kDa}$, which is considered a good index of the extent of proteolysis (O'Reilly et al., 2000). At the beginning of the refrigerated storage, the level of hydrolyzed protein in gels without chymosin was $0.98 \pm 0.07 \%$ and that in calf and camel chymosin gels were $0.90 \pm 0.05 \%$ and $0.91 \pm 0.04 \%$, respectively (Figure 7). We observed no significant differences between the samples immediately after HPP treatment.

Throughout the refrigerated storage, the level of hydrolyzed protein varied from 0.9 to $1.6 \%$ of the average obtained for the 3 milk protein gels. The data showed no clear differences in proteolysis between calf chymosin gels and gels without chymosin. However, on d 28, the level of hydrolyzed protein was higher in the camel chymosin gels $(1.74 \pm 0.10 \%)$ than in the calf chymosin gels $(1.51 \pm 0.02 \%)$. This could be due to a higher inactivation of calf chymosin compared with camel chymosin after HPP treatment at $600 \mathrm{MPa}$. Previous studies also indicated that pressurization $(500-600 \mathrm{MPa})$ reduced the level of proteolysis in cheese via decreased residual activity of calf chymosin (Juan et al., 2007). Additionally, Ricardo et al. (2017) observed a greater exposure of hydrophobic regions for calf chymosin compared with recombinant camel chymosin at $600 \mathrm{MPa}$.

Even if the level of peptides did not show a strong increase, the peptides may lead to a notable increase in bitterness in the MPC samples and any products manufactured using this technology. Therefore, the

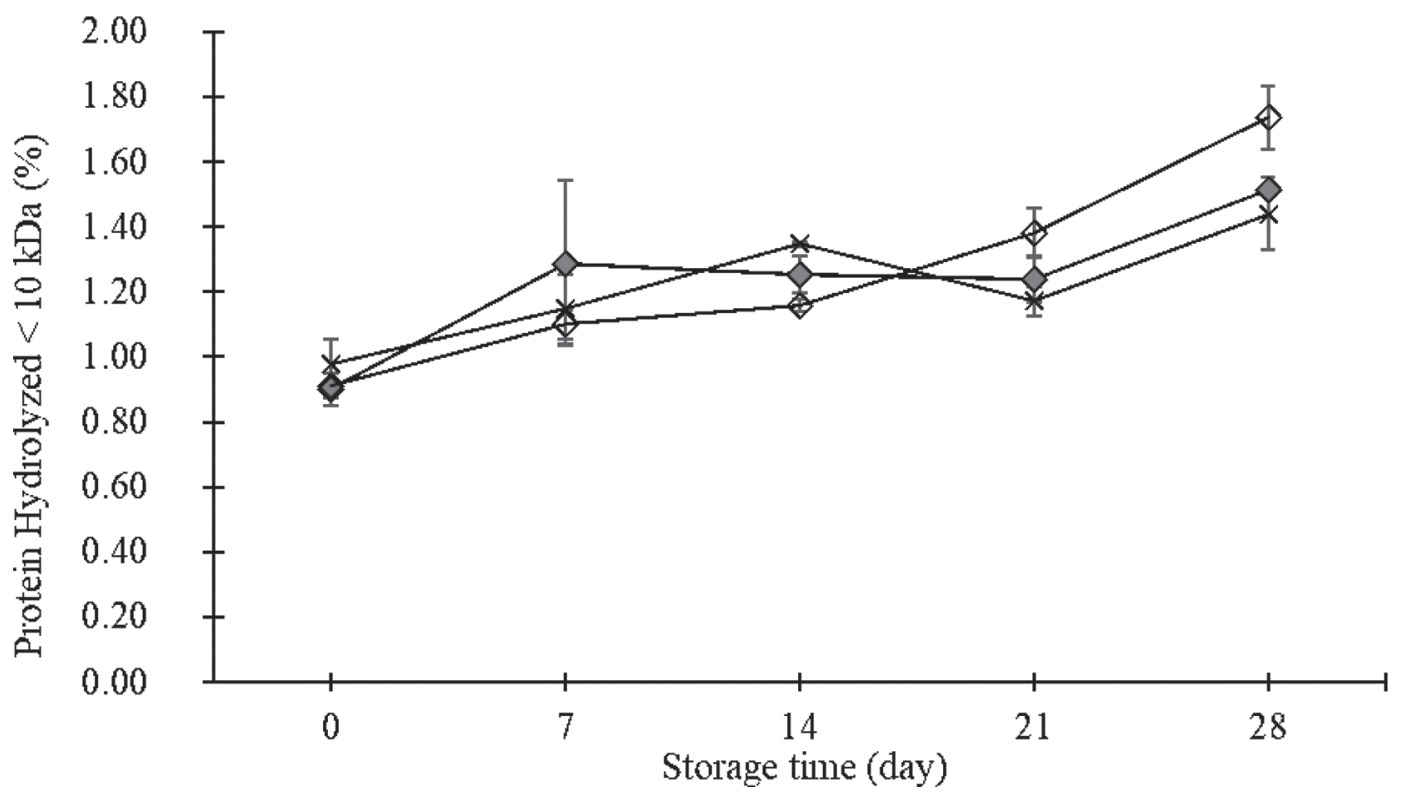

Figure 7. Changes in the percentage of pressure-treated hydrolyzed protein with a molecular mass $<10 \mathrm{kDa}$ for gels without chymosin $(\times)$,

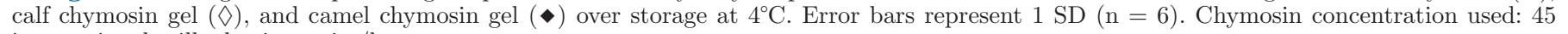
international milk-clotting units $/ \mathrm{kg}$. 
taste implications of this proteolytic activity will need to be assessed in the future using a sensory study.

\section{CONCLUSIONS}

The results of this study demonstrate that all MPC samples formed gels after HPP treatment at $5^{\circ} \mathrm{C}$, and the addition of chymosin reinforced the pressureinduced gels. This is remarkable, because in chymosincatalyzed milk coagulation at atmospheric pressure little aggregation occurs if the temperature is below $10^{\circ} \mathrm{C}$. The combined use of HPP and chymosin resulted in a stronger network and improved refrigerated stability in pressure-induced MPC gels. Overall, this study provides the dairy industry with information necessary to design new structures and novel dairy products, also creating new ways for the utilization of dairy protein ingredients.

\section{ACKNOWLEDGMENTS}

This work was funded by the USDA National Institute of Food and Agriculture (Washington, DC; grant no. 2016-67017-24635) with additional support from the New York State Milk Promotion Advisory Board (Albany, NY). We thank John Joseph Churey and Andy Humiston from Cornell Agri-Tech (Ithaca, NY) for their assistance with the high-pressure treatments, Alexandra E. Hall from Cornell University (Ithaca, NY) for assistance with the peptide concentration measurements, and Hanyu Chen from Cornell University for her support with scanning electron microcopy imaging. The authors have not stated any conflicts of interest.

\section{REFERENCES}

AACC. 2009. Water hydration capacity of protein materials. AACC Approved Methods of Analysis. 11th ed. Cereals and Grains Association (formerly AACC International). https://doi.org/10.1094/ aaccintmethod-56-30.01.

Bamdad, F., S. H. Shin, J.-W. Suh, C. Nimalaratne, and H. Sunwoo. 2017. Anti-inflammatory and antioxidant properties of casein hydrolysate produced using high hydrostatic pressure combined with proteolytic enzymes. Molecules 22:609. https://doi.org/10.3390/ molecules22040609.

Cadesky, L., M. Walkling-Ribeiro, K. T. Kriner, M. V. Karwe, and C. I. Moraru. 2017. Structural changes induced by high-pressure processing in micellar casein and milk protein concentrates. J. Dairy Sci. 100:7055-7070. https://doi.org/10.3168/jds.2016-12072.

Devi, A. F., R. Buckow, Y. Hemar, and S. Kasapis. 2013. Structuring dairy systems through high pressure processing. J. Food Eng. 114:106-122. https://doi.org/10.1016/j.jfoodeng.2012.07.032.

Domagała, J., D. Najgebauer-Lejko, I. Wieteska-Sliwa, M. Sady, M. Wszołek, G. Bonczar, and M. Filipczak-Fiutak. 2016. Influence of milk protein cross-linking by transglutaminase on the rennet coagulation time and the gel properties. J. Sci. Food Agric. 96:35003507. https://doi.org/10.1002/jsfa.7534.
Feng, G., Y. Cheng, S. Wang, L. C. Hsu, Y. Feliz, D. A. Borca-Tasciuc, R. W. Worobo, and C. I. Moraru. 2014. Alumina surfaces with nanoscale topography reduce attachment and biofilm formation by Escherichia coli and Listeria spp. Biofouling 30:1253-1268. https:/ /doi.org/10.1080/08927014.2014.976561.

Fertsch, B., M. Müller, and J. Hinrichs. 2003. Firmness of pressureinduced casein and whey protein gels modulated by holding time and rate of pressure release. Innov. Food Sci. Emerg. Technol. 4:143-150. https://doi.org/10.1016/S1466-8564(03)00008-0.

Grillet, A. M., N. B. Wyatt, and L. M. Gloe. 2012. Polymer gel rheology and adhesion. Chapter 3 in Rheology. J. de Vicente, ed. InTech, Rijeka, Croatia. https://doi.org/10.5772/36975.

Huppertz, T., P. F. Fox, and A. L. Kelly. 2004. Susceptibility of plasmin and chymosin in Cheddar cheese to inactivation by high pressure. J. Dairy Res. 71:496-499. https://doi.org/10.1017/ S0022029904000494.

Juan, B., V. Ferragut, M. Buffa, B. Guamis, and A. J. Trujillo. 2007. Effects of high pressure on proteolytic enzymes in cheese: Relationship with the proteolysis of ewe milk cheese. J. Dairy Sci. 90:2113-2125. https://doi.org/10.3168/jds.2006-791.

Leite Júnior, B. R. C., A. A. L. Tribst, C. F. S. Bonafe, and M. Cristianini. 2016. Determination of the influence of high pressure processing on calf rennet using response surface methodology: Effects on milk coagulation. Lebensm. Wiss. Technol. 65:10-17. https:// doi.org/10.1016/j.lwt.2015.07.063.

Lucey, J. A. 2011. Cheese: Rennet-induced coagulation of milk. Pages 579-584 in Encyclopedia of Dairy Sci. 2nd ed. J. W. Fuquay, ed. Elsevier, Amsterdam, the Netherlands. https://doi.org/10.1016/ B978-0-12-374407-4.00070-4.

Ma, F., C. Chen, G. Sun, W. Wang, H. Fang, and Z. Han. 2012. Effects of high pressure and $\mathrm{CaCl}_{2}$ on properties of salt-soluble meat protein gels containing locust bean gum. Innov. Food Sci. Emerg. Technol. 14:31-37. https://doi.org/10.1016/j.ifset.2011.12.001.

O'Reilly, C. E., P. M. O'Connor, P. M. Murphy, A. L. Kelly, and T. P. Beresford. 2000. The effect of exposure to pressure of $50 \mathrm{MPa}$ on Cheddar cheese ripening. Innov. Food Sci. Emerg. Technol. 1:109117. https://doi.org/10.1016/S1466-8564(00)00011-4.

Renkema, J. M. S., H. Gruppen, and T. Van Vliet. 2002. Influence of $\mathrm{pH}$ and ionic strength on heat-induced formation and rheological properties of soy protein gels in relation to denaturation and their protein compositions. J. Agric. Food Chem. 50:6064-6071. https:/ /doi.org/10.1021/jf020061b.

Ribeiro, L. R., B. R. C. Leite Júnior, A. A. L. Tribst, and M. Cristianini. 2017. Comparative study of the effect of high pressure processing on the residual activity of milk coagulants in buffer and in ultrafiltered cheese. Lebensm. Wiss. Technol. 82:1-7. https:// doi.org/10.1016/j.lwt.2017.04.016.

Leite Júnior, B. R. C., A. A. L. Tribst, N. J. Grant, R. Y. Yada, and M. Cristianini. 2017. Biophysical evaluation of milk-clotting enzymes processed by high pressure. Food Res. Int. 97:116-122. https://doi.org/10.1016/j.foodres.2017.03.042.

Scollard, P. G., T. P. Beresford, E. C. Needs, P. M. Murphy, and A L. Kelly. 2000. Plasmin activity, $\beta$-lactoglobulin denaturation and proteolysis in high pressure treated milk. Int. Dairy J. 10:835-841. https://doi.org/10.1016/S0958-6946(01)00028-0.

Tunick, M. H. 2011. Small-strain dynamic rheology of food protein networks. J. Agric. Food Chem. 59:1481-1486. https://doi.org/10 $.1021 /$ jf1016237.

Wang, L., and C. I. Moraru. 2021. High pressure structuring of milk protein concentrate: Effect of $\mathrm{pH}$ and calcium. J. Dairy Sci. 104:4074-4083. https://doi.org/10.3168/jds.2020-19483.

\section{ORCIDS}

Linran Wang (ํ) https://orcid.org/0000-0002-7363-7673

Carmen I. Moraru ๑ https://orcid.org/0000-0001-8307-7123 